Muller's mind and experiments were working and the political and academic atmosphere, including intrigues, in which they worked. Fascinating are the accounts of Muller's periods in the Soviet Union (1933-1937), where he was the most influential and active dissident against the Lysenko madness, in the Spanish Civil War, in Edinburgh (November 1937September 1940) and, finally, in his efforts towards an international ban on atomic bomb tests. In spite of the few inaccuracies which I could spot in the Edinburgh events from first-hand knowledge, the accounts seem to be mainly reliable.

The Nobel Prize won by Muller in 1946 was awarded not for his theoretical contribution of 1921 or for his major share in clearing up the mechanism of Mendelian heredity or for turning mutation from an act of God into an event of measurable recurrence or for pioneer work on human twins, but for having demonstrated in 1926 that $\mathrm{X}$-rays increase mutation rate. This,

\section{'Muller's classic papers}

"Variation due to change in the individual gene" (Amer. Nat. 56, 32-50; 1922). "The gene as the basis of life" (Proc. Int. Congr. Plant Sci. 1, 897-921; 1929). "The gene material as the initiator and organizing basis of life" (Amer. Nat. 100, 493-517; 1966). A full list of H.J. Muller's papers is in Biographical Memoirs of the Royal Society 14, 349-389; 1968.

\section{Stains}

EM Science manufactures JANUS GREEN and other important MCB biological and high purity stains. EM Science. . Quality and Service for over 50 years.

Acid Fuchsin, Stain

Basic Fuchsin, Stain

Bromocresol Green, Indicator Bromothymol Blue

Janus Green Safranin O Methyl Red Thymol Blue Phenol Red For further information, call Bulk Reagent Sales (609) 423-6300

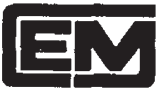

EM SCIENCE

Bulk Reagent Sales 480 Democrat Road Gibbstown, NI 08027 A Diviaton ent EM Industries. Inc Ancociate of 5 . Nerch Darmstadt Ceerman

Circle No.14 on Reader Service Card. of course, was of topical practical importance in 1946, after Hiroshima, but can be considered only as a fall-out of other work.

The increased responsibility which Muller felt after the award, made him turn increasingly to what was the preoccupation in his youth, the necessity of consciously shaping the feedback between genetics and culture for the future of mankind. His suggestion of voluntary germinal selection for artificial insemination by using preserved sperm produced reactions from plain derision to violent denunciation. Time will tell.

This biography is of course essential reading for the students of the history of biology. Let us also hope that it will induce some of those young molecular biologists to read three of Muller's most significant papers $^{1}$ : those of 1921,1926 and 1965, published in 1922, 1929 and 1966.

Guido Pontecorvo was Consultant Geneticist at the Imperial Cancer Research Fund, London, until 1980, and worked with Muller at the University of Edinburgh from 1938 to 1940.

\title{
Updating the Old Stone Age
}

\section{John A.J. Gowlett}

The Palaeolithic Age. By John Wymer. Pp.310. UK ISBN 0-7099-2710-X; US ISBN 0-312-59476-3. (Croom Helm/St Martin's Press: 1982.) £16.95, \$35.

Human evolution as a study has a curious and persisting interest which may stem partly from the notion that had it not happened we would not be here to study it or anything else. Numerous books reflect this fascination, but most popular surveys concentrate on one side of the evidence, the biological rather than the archaeological part of the story. Although biologists (notably Julian Huxley) have explored the interplay between the biological and psychosocial aspects of human evolution, the two are still conveniently amenable to separation. Since there is little doubt that primates, ethology and early hominids have fared better in broad and popular surveys, it is time again for archaeology to do its bit. This is especially so as the standard texts of early archaeology are at least a decade out of date, now painfully lacking in references to new sites and dates.

John Wymer's The Palaeolithic Age thus helps to bridge a large gap, specifically, as is his intention, that between short summaries of the Old Stone Age and the specialized papers of journals. This, however, is a less easy task than it used to be: over the past 20 years fieldwork has been undertaken in many countries, and new techniques of study are developing all the time. It was just possible to be an allround expert of the Old Stone Age, but this is no longer the case. Nonetheless John Wymer has sound credentials for his undertaking, with a wealth of excavation experience both in Europe and Africa.

Wymer's approach is to get straight on with the job, to take advantage of the natural framework of time, and to tell the story concentrating on the stone tools as the most tangible remains. Other lines of evidence are treated, but not to the same extent. He emphasizes continuity, the choice of a title for his book itself reflecting continuity with an older generation of antiquaries. The result is a useful digest of
Stone Age sites in most parts of the world, handsomely covering some areas, but undoubtedly bitty in parts, and cast in a framework more idiosyncratic than it appears at first glance.

Sound as most of the factual material is, chapter headings such as "Unspecialised Hunter-Gatherers" are highly loaded: rightly or wrongly, many archaeologists think in terms of scavenging rather than hunting for the earlier periods. "Unspecialised", too, is an assumption. If that assumption is accepted, detailed discussions about other lines of evidence can indeed be reserved for later chapters, as Wymer does.

Interesting in a modern book is the adoption in modified form of the old savagery and barbarism model, developed by Morgan and used by Marx. Childe set the transition from savagery to barbarism at the origins of food production, but Wymer sets it back many thousands of years to the Mousterian, and I can only wonder whether its continued use really aids our understanding. Then, in Wymer's framework, the Upper Palaeolithic is seen implicitly as a world-wide phase, though technically it refers to a particular technology not present everywhere. It is no fault of Wymer's that he cannot squeeze everything between these covers. Europe and Africa are done well, but the omission of the Nile sequence, and of Japan in totality, seems surprising. Highly compressed treatment of the early settlement of Australia and the Americas was probably a necessity, but could limit the appeal of the book in those areas.

These points emphasize that Wymer has provided a personal view of the Palaeolithic, rather than a standard textbook. As such it will not entirely replace previous surveys of the period, but it is without doubt "a valuable complementary source for relatively detailed information about the Old Stone Age.

J.A.J. Gowlett is at the Research Laboratory for Archaeology, University of Oxford. 